\title{
FOOD PREFERENCE OF GIANT ANTEATER AND COLLARED ANTEATER (Pilosa, Myrmecophagidae) REGARDING THE TERMITE DEFENSE STRATEGIES
}

\author{
PREFERENCIA ALIMENTAR DE TAMANDUÁ BANDEIRA E DE TAMANDUÁ \\ MIRIM (Pilosa, Mirmecophagidae) EM RELAÇÃO À ESTRATÉGIA DE DEFESA DOS \\ CUPINS
}

\author{
Hélida Ferreira da CUNHA ${ }^{1}$; Tiago Fernandes CARRIJO ${ }^{2,3}$; Anna Carolina PRESTES ${ }^{4}$; \\ Lucas Souza ARRUDA ${ }^{5}$; Pollyane B. REZENDE ${ }^{6}$; Thiago SANTOS $^{7}$; Divino BRANDÃO ${ }^{7}$ \\ 1. Universidade Estadual de Goiás, Anápolis, GO, Brazil. cunhahf@gmail.com; 2. Museu de Zoologia da Universidade de São Paulo, \\ São Paulo, SP, Brazil; 3. Faculdade de Filosofia Ciências e Letras de Ribeirão Preto, Ribeirão Preto, SP, Brazil; 4. Universidade de \\ Brasília, Brasília, DF, Brazil; 5. Universidade Federal Rural de Pernambuco, Recife, PE, Brazil; 6. Secretaria Municipal de Meio \\ Ambiente, Anápolis, GO, Brazil; 7 Universidade Federal de Goiás, Goiânia, GO, Brazil.
}

\begin{abstract}
Giant (Myrmecophaga tridactyla) and collared anteaters (Tamandua tetradactyla) are common mammals in the Cerrado biome. They are specialized in eating termites (Isoptera, Blattaria) and ants (Formicidae, Hymenoptera). This study tested the preference of the giant anteater for termites with different defense strategies: 1) soldier with chemical defense and a soft nest (Nasutitermes), and 2) soldier with mixed defenses - chemical and mechanical - and a hard nest (Cornitermes). Pieces of nests of both genera of termites were provided to captive giant anteaters, their behaviors were observed, and the time spent feeding in each termite nests was recorded. The anteaters exploited both termite species, although no significance difference was found, they spent more time feeding on Cornitermes than on Nasutitermes. The stomach contents of one road-killed giant anteater and one collared anteater were analyzed. The collared anteater fed on a wider diversity of termite species with different defense strategies, but showed a preference for Cornitermes. We argue that the preference of anteaters for a termite species that has a harder nest, and soldiers with mixed defense, may be due to the presence of terpenoids in the chemical apparatus of Nasutitermes, absent in Cornitermes. Also, the much higher proportion of soldiers in Nasutitermes may influence the anteaters' choice.
\end{abstract}

KEYWORDS: Isoptera. Ants. Cerrado. Zoo. Stomach contentes

\section{INTRODUCTION}

The giant (Myrmecophaga tridactyla Linnaeus, 1758) and collared anteaters (Tamandua tetradactyla Linnaeus, 1758) are common mammals in the Cerrado biome (South American savanna). The former is nocturnal and crepuscular, and feeds mainly on the ground but is also able to climb trees and large termite nests (RUMMEL, 1988; YOUNG et al., 2003); while the latter is nocturnal and feeds mainly in the treetops, but may also search for food on the ground (YOUNG et al., 2003; MEDRI et al., 2006). Both species are under constant threat from highway road kills, deforestation, grassland burning, and hunting (MIRANDA; MEDRI, 2010).

These anteaters are specialized in eating termites (Isoptera, Blattaria) and ants (Formicidae, Hymenoptera). They have large strong claws to open termite and ant nests, and a conical head with a tubular mouth and long sticky tongue to capture these insects inside their galleries and tunnels (MEDRI et al., 2006).

Termites and ants together compose only $2 \%$ of insect species; however, they are the most abundant animals on earth (KORB, 2008) and comprise more than half of the insect biomass (WILSON; HÖLLDOBLER, 2005). Due to this high biomass and abundance, mainly the termites are at the base of many food chains. Termites have evolved many defense strategies against predators, which can be divided into two components: the individuals of the colony (soldier and worker castes) and the nest (structure and location).

The soldier caste in termites is almost exclusively for colony defense, and different species have different kinds of soldiers. In some species (most members of the subfamily Termitinae, for instance, but see Šobotník et al. 2012), the soldiers have an almost strictly mechanical defense mechanism: this is, their only weapon is their mandibles, and they can only bite their predator. In other species (Syntermitinae) the soldiers have a mixed defense mechanism: they have both mandibles (for biting) and a frontal tube on the head, which is connected to a gland in the head, and expels chemical substances that may cause irritation, or may be toxic, or even glue the predator. Finally, some species have strictly chemical defense mechanisms (Nasutitermitinae): the soldiers have vestigial mandibles, and the frontal tube is the only 
weapon against predators (PRESTWICH, 2004; SCHOLTZ et al., 2008).

The proportion of workers and soldiers in the colony varies among species, and this, together with the other above-mentioned defense strategies, can affect the efficiency of defense against one or another predator (COLES de NEGRET; REDFORD, 1982). Although the worker caste in termites was traditionally thought to participate little in colony defense, this is not true for many species. The defense mechanisms of the worker caste include biting, defecating, or even "exploding" themselves for the colony defense (ŠOBOTNÍK et al., 2012; ŠOBOTNÍK et al., 2010).

Finally, many species of termites build nests for both temperature control and colony defense. The nests, depending on the species, may be hard or soft, composed mainly of soil or carton (plant particles), and may be subterranean, epigeal (aboveground) or arboreal (NOIROT; DARLINGTON, 2000).

In the Cerrado biome in Central Brazil, termites are extremely abundant, and many species build epigeal nests (REDFORD, 1984). Because the giant anteater feeds mainly on these epigeal termite nests, we tested the preference of this predator between two termite species that build epigeal nests: Nasutitermes sp. and Cornitermes sp. The first has a soft nest, and soldiers with strictly chemical defense, but in a much higher proportion in the colony; the second has a hard nest, and soldiers with mixed defenses, but these are present in a lower proportion (COLES de NEGRET; REDFORD, 1982). Also, to compare the defense strategies between the termites eaten by the giant and collared anteaters and to obtain information about and evaluate the diet overlap between both species of anteaters, we analyzed the stomach contents of one individual from each species.

\section{MATERIAL AND METHODS}

\section{Observations at the Zoo}

In the Goiânia Zoo (Goiás, Brazil), the captive anteaters feed mainly on a mix of milk and fruits, sporadically receiving termites as a food supplement. For this experiment, thirteen nests from two genus of termite that build epigeal nests were used: Cornitermes sp. and Nasutitermes sp. The first has a hard nest, and soldiers with mixed defenses that comprise a low proportion of the colony; the second has a soft nest, and soldiers with strictly chemical defense, but in a much higher proportion in the colony.
The nests were collected in a farm near Goiânia, and brought to the zoo, stored in plastic bags, on the day preceding the observations. The termite nests, or pieces of approximately $40 \mathrm{~cm}^{3}$, were placed in the anteaters' enclosure, $40 \mathrm{~cm}$ distant from each other. The total time, in seconds, spent by each anteater feeding on each termite species was recorded, using a timer. Four giant anteaters were observed in different years, totalizing 18 observations: five days of observation for each anteaters in 2005, and four days of observation for two others anteaters in 2008 and in 2009.

The food preference between the nasute or mixed-defense termites by the giant anteater was statistically compared by Wilcoxon test, for the total time that each anteater spent feeding on the termite nests.

\section{Stomach contents}

The stomach of $T$. tetradactyla (collared anteater) examined was from an adult female recently killed on highway GO-060 between Arenópolis and Piranhas $\left(16^{\circ} 25^{\prime} 05^{\prime \prime} \mathrm{S}\right.$ and $\left.51^{\circ} 37^{\prime} 56^{\prime} \mathrm{W}\right)$. One preserved stomach contents of M. tridactyla was donated by the Laboratório de Zoologia da Universidade Federal de Goiás (LabZoo/ UFG), and was from an adult killed near the Parque Estadual Altamiro Moura Pacheco (PEAMP) on highway BR-153 between Goiânia and Anápolis $\left(16^{\circ} 34^{\prime} 56^{\prime \prime} \mathrm{S}\right.$ and $\left.49^{\circ} 10^{\prime} 46^{\prime \prime} \mathrm{W}\right)$. The vicinity of BR153 , consisting of a Conservation Unit covering 3746 ha (PEAMP, 2008), is more preserved than the area surrounding GO-060, which is bordered by farms. The highway stretches where the road-killed anteaters were found are surrounded by fragments of Semideciduous Forest fragments within an agropastoral matrix and fragments of Cerrado.

The stomach content of each anteater was first washed with water to remove excess soil. Then, the food items were sorted under a stereomicroscope, and the samples, stored in vials with $70 \%$ ethanol, were deposited in the collection of the Laboratório de Pesquisa Ecológica e Educação Científica da Universidade Estadual de Goiás (Lab-PEEC/ UEG). Taxonomic determination of food items followed the specialized bibliography (CONSTANTINO, 1999; FERNÁNDEZ, 2003). It was not possible to determine all the species of termites and ants, because the majority of specimens were fragmented.

The wet weight for each food item was obtained with a balance accurate to $0.01 \mathrm{~g}$. The relative importance (\%) of the food items was measured as the weight of the item, and the ratio to the total weight of the food items. Items that could 
not be identified due to the advanced degree of digestion were designated as undetermined organic matter. The overlap feed was estimated considering the relative frequency of each food item, according to the Pianka index (1973), which ranges from 0 (no overlap) to 1 (complete overlap), through the program EcoSim ${ }^{\circledR}$ (GOTELLI; ENTSMINGER, 2001).

\section{RESULTS}

\section{Observations at the Zoo}

In most of the observations, the captive giant anteaters perceived the presence of the nest of Nasutitermes sp. before that of Cornitermes sp. As they approached the nests, the anteaters sniffed for awhile (mean of $92 \mathrm{~s}$ in Nasutitermes sp. and $132 \mathrm{~s}$ in Cornitermes sp.), scratched (mean of $5 \mathrm{~s}$ in Nasutitermes sp. and $21 \mathrm{~s}$ in Cornitermes sp.), and finally started to eat (Table 1).

The anteaters spent more time feeding on Cornitermes sp. (8252 s versus 3184 s). However, the difference was not significant $(\mathrm{P}=0.29)$. Of the total of 18 observations, on only one day the "anteater A" spend more time feeding on Nasutitermes than on Cornitermes. In all other observations, the anteaters spent most of the time or all the time feeding on Cornitermes. Moreover, in a single observation in 2005, the "anteater A" spent 2037 s on the Nasutitermes and only 76 on Cornitermes. This was a huge outlier observation that resulted in a more similar overall average between the two treatments.

Table 1. Feeding time (in seconds) of giant anteaters in nests of Cornitermes sp. and of Nasutitermes sp. (mean \pm standard deviation), number of days of observations at the zoo (n) and P value to Wilcoxon test.

\begin{tabular}{ccccc}
\hline Anteaters & Cornitermes & Nasutitermes & $\mathrm{n}$ & $\mathrm{P}$ \\
\hline Anteater A/ 2005 & $318.8 \pm 380.8$ & $521.2 \pm 851.3$ & 5 & 0.68 \\
Anteater B/ 2005 & $861.2 \pm 777.1$ & 0 & 5 & 0.04 \\
Anteater C/ 2008 & $304.5 \pm 155.3$ & $103.3 \pm 51.4$ & 4 & 0.07 \\
Anteater D/ 2009 & $283.5 \pm 179.5$ & $41.3 \pm 70.4$ & 4 & 0.07 \\
\hline Total & $458.4 \pm 502.3$ & $176.9 \pm 470.7$ & 18 & 0.29 \\
\hline
\end{tabular}

\section{Stomach contents}

The stomachs of the two anteaters were obtained from road-killed animals, and it is assumed that the contents came from their last meal. A higher proportion of unidentified stomach contents were found in M. tridactyla than in T. tetradactyla $(71 \%$ versus $17 \%$, Table 2). These unidentified stomach contents were composed of semi-digested bodies of workers and larvae, and it was not possible even to discriminate between ants and termites.

The stomach content of $T$. tetradactyla weighed $109.15 \mathrm{~g}$, including $53 \%$ ants, $29 \%$ termites, $17 \%$ unidentified material and $0.7 \%$ bees (Table 2). The stomach content of M. tridactyla weighed $133.71 \mathrm{~g}$, of which $71 \%$ was unidentified material, $17 \%$ termites, $11 \%$ ants and $0.2 \%$ nematodes (Table 2). The stomach of T. tetradactyla contained a high diversity of food items: eight ant species, six termite species and a kind of bee; while the stomach of $M$. tridactyla contained three species of ants and two of termites (Table 2). There is high dietary overlap between $M$. tridactyla and $T$. tetradactyla $(0.79, \mathrm{P}=0.005)$.

Table 2. Food items in grams $(\mathrm{g})$ and percentage (\%) of the stomach contents of M. tridactyla and of $T$. tetradactyla.

\begin{tabular}{ccccc}
\hline Food item & \multicolumn{2}{c}{ M. tridactyla } & \multicolumn{2}{c}{ T. tetradactyla } \\
& $(\mathrm{g})$ & $(\%)$ & $(\mathrm{g})$ & $(\%)$ \\
\hline Content unidentified & 95.41 & 71.3559 & 18.83 & 17.2515 \\
Ant eggs & 10.40 & 7.7780 & 32.95 & 30.1878
\end{tabular}




\begin{tabular}{|c|c|c|c|c|}
\hline Camponotus rufipes & 3.20 & 2.3932 & 6.51 & 5.9643 \\
\hline Camponotus sp.1 & 0 & 0 & 17.60 & 16.1246 \\
\hline Camponotus sp.2 & 0.30 & 0.2244 & 0 & 0 \\
\hline Ectatoma sp. & 0 & 0 & 0.50 & 0.4581 \\
\hline Brachymyrmex sp. & 0 & 0 & 0.02 & 0.0053 \\
\hline Neivamyrmex sp. & 0 & 0 & 0.00005 & 0.0027 \\
\hline Pheidole sp. & 0 & 0 & 0.10 & 0.0916 \\
\hline Solenopsis sp. & 0.60 & 0.4487 & 0.16 & 0.0040 \\
\hline Gigantiops sp. & 0 & 0 & 0.02 & 0.0100 \\
\hline Worker termites & 20.20 & 15.1073 & 20.90 & 19.1480 \\
\hline Rhynchotermes diphyes & 0 & 0 & 0.60 & 0.5497 \\
\hline Microcerotermes sp. & 0 & 0 & 0.01 & 0.0073 \\
\hline Nasutitermes sp. & 0 & 0 & 1.60 & 1.4659 \\
\hline Heterotermes sp. & 0 & 0 & 0.08 & 0.0733 \\
\hline Coptotermes sp. & 0 & 0 & 0.50 & 0.4581 \\
\hline Cornitermes silvestrii & 3.30 & 2.4680 & 8.10 & 7.4210 \\
\hline Diversitermes sp. & 0 & 0 & 0.05 & 0.0458 \\
\hline Meliponini & 0 & 0 & 0.80 & 0.7329 \\
\hline Nematoda & 0.30 & 0.2244 & 0 & 0 \\
\hline TOTAL & 133.71 & 100.00 & 109.15 & 100.00 \\
\hline
\end{tabular}

\section{DISCUSSION}

The tests of feeding preference with captive M. tridactyla revealed that the individuals exploited both termite species, with no significant preference for either. However, on average, they spent more time feeding on termites with a mixed defense mechanism and a hard nest (Cornitermes), than on those with only a chemical defense mechanism and a soft nest (Nasutitermes).

Termite individuals have low nutritional value, except for the reproductive caste, which are few in number in termite nests during much of the year (REDFORD; DOREA, 1984). But, the soldiers of Cornitermes have more fat than the Nasutitermes (REDFORD; DOREA, 1984). Therefore, predation by mammals on these organisms is based on other factors, among them the kind of defenses of the different species, like nests type or species that have large proportion of workers than soldiers (REDFORD; DOREA, 1984). The results presented here indicate a slight preference of anteaters to spend more time feeding in nests of Cornitermes than of Nasutitermes.

As previously mentioned, although the proportion of soldiers in the nests is usually much lower in Cornitermes than in Nasutitermes, the nests of Cornitermes are harder and the soldiers of the species of this genus have both chemical and mechanical defenses, in comparison to of Nasutitermes, that have only chemical defense. Then, one could imagine that Nasutitermes would be preferred by anteaters, but apparently this does not occur, and our results corroborate previous studies. Redford (1985) found that captive giant anteaters preferred to eat members of the 
Syntermitinae genera Cornitermes and Procornitermes over the Nasutitermitinae Cortaritermes, Nasutitermes and Velocitermes. Similarly, in an experiment by Coles (1980), the giant anteater preferred the Syntermitinae genera Cornitermes, Syntermes, and Procornitermes, while the least preferred were the genera Nasutitermes and Velocitermes (Nasutitermitinae).

What specific features of their strategies increase the efficiency of Nasutitermitinae in defending against anteaters? An important aspect is that the soldiers of the subfamily Nasutitermitinae produce mixtures of monoterpenes and diterpenes, frequently with other compounds (alcohols, ketones, aromatic compounds, amides) as well. This complex secretion has different functions, depending on the species and its composition. It can function as a glue, an irritant, a repellent to enemies, and/or act as an alarm pheromone (ŠOBOTNÍK et al., 2012). The soldiers of Syntermitinae have well-developed mandibles, which are absent or vestigial in Nasutitermitinae, to pierce the enemy and hold it while the frontal-gland secretion is released by the nasus. However, the compounds forming this secretion are much less complex. Members of Cornitermes have three categories of compounds, macrocyclic lactones, N-heterocycles and aromatic compounds, some of which have an irritant effect on ants (ŠOBOTNÍK et al., 2012; BLUM et al., 1982). Therefore, the volatile terpenoids produced by the frontal gland of Nasutitermes probably are a strong irritant to the olfactory glands of anteaters.

In addition to the substances produced by termites, their behavior with respect to predation can also contribute to the efficacy of defense: the large proportion of soldiers produced by Nasutitermes (in comparison to the smaller proportion of soldiers produced by Cornitermes), the rapid recruitment of nasute soldiers to where the predator started the attack, and consequent large quantity of terpenes launched by these soldiers, can discourage predators. In the case of Cornitermes, the soldiers are not recruited as quickly to the affected area, and the majority remains within the mound. In this way, the large amounts of secretion produced by a species with a high proportion of soldiers may affect the overall palatability of the food (WALLER; LaFAGE, 1987).

Finally, the resistance of the nest may confer an advantage. The resistance of the nests of Cornitermes is much greater than the resistance of the nests of Nasutitermes (COLES de NEGRET; REDFORD, 1982), implying that the predator has greater difficulty in reaching the termites inside. This advantage of Cornitermes is even greater if we take into account the hiding behavior of these termites, where most individuals of the colony go to the center of the nest when disturbed. However, this advantage is only apparent: anteaters, even younger individuals, can easily break the nests.

The preference of giant anteaters for Cornitermes was also observed in the analysis of stomach contents. The only termite genus identified in the stomach contents of $M$. tridactyla was Cornitermes. The giant anteater might have ingested only Cornitermes for lack of choice; however, analysis of the stomach contents of the collared anteater showed that the area has several other species (and genera) of termites.

These two species of anteaters have very different life habits, as apparent from the difference in stomach contents of the two individuals. The giant anteater is more vagile than the collared anteater because of the size of the home range. $M$. tridactyla may have a territory of up to $11.9 \mathrm{~km}^{2}$ (MEDRI; MOURÃO, 2005), while that of $T$. tetradactyla is only up to $3.4 \mathrm{~km}^{2}$ (HAYSSEN, 2011; RODRIGUES et al., 2001). However, apparently $T$. tetradactyla has a greater diversity of feeding habits. The high dietary overlap between the two species of anteater is explained by the presence majority in stomach contents of Cornitermes silvestrii and in minor proportion of ants Camponotus rufipes and Solenopsis sp.

The collared anteater fed on both Cornitermes (similarly to the giant anteater), which build epigeal nests, as well as on other termite genera with different biology. Although the possibility exists that the collared anteater had fed on only one nest of Cornitermes with multiple inquilines (nests of species of this genus can house 15 or more other species of termites; Redford 1984), the diversity of termites indicates that this individual was foraging on termites in other microhabitats.

The Nasutitermes was not identified to species level, and species of this genus can build both epigeal and arboreal nests. It is therefore not possible to say where the collared anteater was eating these individuals. Species of Microcerotermes in the Cerrado always build arboreal nests, but individuals of these colonies can be found outside the nest, inside galleries on tree trunks, or even in nests of other species (such as Cornitermes). Species of the genera Heterotermes and Coptotermes can also be found in nests of other species, although they are usually found foraging in dead wood. Finally, the members of the genera Diversitermes and Rhynchotermes are typically found on the surface of the ground, foraging on leaf litter. Thus, the collared anteater apparently seeks its 
food in termite mounds on the ground, in trees, in dead wood, and in the soil.

Almost all genera of ants found in the stomach contents of $T$. tetradactyla are commonly found in termite mounds of Cornitermes (REDFORD, 1984; COSTA et al., 2009; CUNHA; MORAIS, 2010). More than $30 \%$ of the stomach contents of $T$. tetradactyla were ant eggs; some ant species establish their nest inside termite mounds. In Colombia, Sandoval-Gómez et al. (2012) reported a higher percentage of arboreal ants in the feces of $T$. tetradactyla and $T$. mexicana, but also found termites of the genus Cornitermes. For $M$. tridactyla, they reported exclusively soil ants, in addition to Cornitermes and a species of Nasutitermitinae.

In general, the results suggest that $M$. tridactyla had fed on an epigeal mound of Cornitermes sp., probably cohabited by C. rufipes and Camponotus sp. These ants are common in the diet of this species and are usually found in termite
CUNHA, H. F. et al

mounds (REDFORD, 1984, 1985; COSTA et al., 2009; CUNHA; MORAIS, 2010).

Thus, $M$. tridactyla and $T$. tetradactyla had similar diets, when you consider that both consumed the same types of food resources, such as, a lot of termite workers of $C$. silvestrii and ant eggs of $C$. rufipes and of Solenopsis sp. However, the diversity and the proportions of these resources in the stomach contents differed among species of anteater.

\section{ACKNOWLEDGMENTS}

Support was provided by the Conselho Nacional de Desenvolvimento Científico e Tecnológico (CNPq), Scientific Initiation scholarships (to ACP, PBR and TS); and by the Coordenação de Aperfeiçoamento de Pessoal de Nível Superior (CAPES), Ph.D. scholarship (to TFC).

RESUMO: Tamanduá-bandeira (Myrmecophaga tridactyla) e Tamanduá-mirim (Tamandua tetradactyla) são mamíferos comuns no bioma Cerrado. São espécies especializadas em se alimentar de cupins (Isoptera, Blattaria) e de formigas (Formicidae, Hymenoptera). Este trabalho testou a preferência de tamanduás-bandeira por cupins com diferentes estratégias de defesa: 1) soldados com defesa química e ninho macio (Nasutitermes) e 2) soldados com defesa mista química e mecânica - e ninho duro (Cornitermes). Pedaços de ninhos de ambos os gêneros de cupins foram fornecidos para tamanduás-bandeira em cativeiro, seu comportamento foi observado e o tempo gasto para se alimentar em cada ninho foi registrado. Os tamanduás exploraram os dois tipos de ninhos, apesar de não haver diferença significativa, eles permaneceram mais tempo se alimentando de Cornitermes do que de Nasutitermes. Os estômagos de um tamanduábandeira e de um tamanduá-mirim atropelados em rodovias foram utilizados para analisar a dieta das espécies. O conteúdo estomacal do tamanduá-mirim revelou uma maior diversidade de espécies de cupins com diferentes estratégias de defesa, mas mostrou uma preferência por Cornitermes. Discutimos que a preferência de tamanduás por espécies de cupins com soldados de defesa mista e que constroem ninhos duros, pode ser devido à presença de terpenos no sistema de defesa de Nasutitermes, ausente em Cornitermes. Além disso, uma proporção superior de soldados em Nasutitermes pode influenciar a escolha dos tamanduás.

PALAVRAS-CHAVE: Isoptera. Formigas. Cerrado. Zoológico. Conteúdo estomacal.

\section{REFERENCES}

BLUM, M. S.; JONES, T. H.; HOWARD, D. F.; OVERAL, L.; Biochemistry of termite defenses Coptotermes, Rhinotermes and Cornitermes species, Comparative Biochemistry and Physiology BBiochemistry \& Molecular Biology, v. 71B, n. 4, p. 731-733, 1982. http://dx.doi.org/10.1016/0305-0491(82)90489-8

COLES de NEGRET, H. R.; REDFORT, K. H. The biology of nine termite species (Isoptera: Termitidae) from cerrado of Central Brazil, Psyche, New York, v. 89, p. 81-106, 1982.

COLES de NEGRET, H. R. Defensive strategies in the ecology of Neotropical termites. Ph.D. thesis Southampton University, Reino Unido, 243 p, 1980.

CONSTANTINO, R., Chave ilustrada para identificação dos gêneros de cupins (Insecta-Isoptera) que ocorrem no Brasil, Papéis Avulsos de Zoologia, São Paulo, v. 40, p. 387-448, 1999. 
COSTA, D. A; CARVALHO, R. A.; LIMA FILHO, G. F.; BRANDÃO, D. Inquilines and Invertebrate Fauna Associated With Termite Nests of Cornitermes cumulans (Isoptera, Termitidae) in the Emas National Park, Mineiros, Goiás, Brazil, Sociobiology, Chicago, v. 53, n. 2B, p. 443-453, 2009.

CUNHA, H. F.; MORAIS, P. P. A. M.; Relação Espécie-Área em Cupinzeiros de Pastagem, Goiânia-GO, Brasil, EntomoBrasilis, Vassouras, v. 3, n. 3, p. 60-63. 2010.

FERNÁNDEZ, F.,(ed.). Introducción a las Hormigas de la región Neotropical. Instituto de Investigación de Recursos Biológicos Alexander von Humboldt, Bogotá, Colombia. XXVI + 398 p. 2003.

HAYSSEN, V. Tamandua tetradactyla (Pilosa: Myrmecophagidae), Mammalian Species, Washington, v. 43, n. 1, p. 64-74, 2011.

KORB, J. J. The ecology of social evolution in termites, In Ecology of Social Evolution, KORB, J. J.;

HEINZE, E. Springer Press, Heidelberg, Edinburgh, p. 151-174, 2008. http://dx.doi.org/10.1007/978-3-540-75957-7

MEDRI, I. M.; MOURÃO, G. M.; RODRIGUES, F. H. G. (Ordem Xenarthra), In N.R. REIS; PERACCHI A, L.; PEDRO, W. A.; LIMA I. P. Mamíferos do Brasil. Londrina: NELIO R. dos REIS, 437 p. 2006.

MEDRI, I. M.; MOURÃO, G. M. Home range of giant anteaters (Myrmecophaga tridactyla) in the Pantanal wetland, Pantanal, Brazil, J. Zool., Lond., London, v. 266, p. 365-375, 2005.

MIRANDA, F.; MEDRI, I. Myrmecophaga tridactyla, 2010. In IUCN 2012. IUCN Red List of Threatened Species. Version 2012.1. <www.iucnredlist.org>. Downloaded on 31 July 2012.

NOITOT, C.; DARLINGTON, J. P. E. C.; Termite Nests: Architecture, Regulation and Defense, In Abe T.; BIGNELL, D.; HIGASHI, M.E. Termites: Evolution, Sociality, Symbioses, Ecology, Kluwer Academic Publishers, p. 121-139. 2000.

PRESTWICH, G. D.; Defense Mechanisms of Termites, Annual Review of Entomology, Palo Alto, v. 29, p. 201-232, 1984. http://dx.doi.org/10.1146/annurev.en.29.010184.001221

REDFORD, K. H. Mammalian predation on termites: tests with the burrowing mouse (Oxymycterus roberti) and its prey, Oecologia, Cambridge, v. 65, p. 145-152. 1984. http://dx.doi.org/10.1007/BF00384477

REDFORD, K. H. Feeding and food preference in captive and wild giant anteaters (Myrmecophaga tridactyla), Journal of Zoology, London, v. 205, n. 4, p. 559-572. 1985. http://dx.doi.org/10.1111/j.1469-7998.1985.tb03544.x

REDFORD, K. H.; DOREA, J. G. The nutritional value of invertebrates with emphasis on ants and termites as food for mammals, Journal of Zoology, London, v. 203, p. 385-395, 1984.

http://dx.doi.org/10.1111/j.1469-7998.1984.tb02339.x

RODRIGUES, F. H. G.; MARINHO-FILHO, J.; SANTOS, H. G. Home ranges of translocate lesser anteaters Tamandua tetradactyla in the cerrado of Brazil, Oryx, Cambridge, v. 35, n. 2, p. 166-169 2001. http://dx.doi.org/10.1017/S0030605300031732

RUMMEL, R. G. Arboreal activity in a captive giant anteater (Myrmecophaga tridactyla). Animal Keeper's Forum, North Carolina, v. 15, n. 1, p. 16-17, 1988.

SANDOVAL-GOMEZ, V. E.; RAMÍREZ-CHAVES, H. E.; MARÍN, D. Registros de hormigas y termitas presentes en la dieta de osos hormigueros (Mammalia: Myrmecophagidae) en tres localidades de Colombia, Edentata, Arlington, v. 13, p. 1-9, 2012. http://dx.doi.org/10.5537/020.013.0104

SCHOLTZ, O. I. ; MACLEOD, N.; EGGLETON, P. Termite soldier defence strategies: a reassessment of Prestwich's classification and an examination of the evolution of defence morphology using extended 
eigenshape analyses of head morphology, Zoological Journal of the Linnean Society, Londres, v. 153, p. 631-650. 2008.

ŠOBOTINÍK, J.; HANUS, R.; JIROSOVÁ, A. Chemical warfare in termites, Journal of Insect Physiology, v. 56, n. 9, p. 1012-1021, 2010. http://dx.doi.org/10.1016/j.jinsphys.2010.02.012

ŠOBTNIK, J.; BOURGUIGNON, T.; HANUS, R.; DEMIANOVÁ, Z.; PYLTEKOVÁ, J.; MARÉS, M.;

FOLTYNOVÁ, P.; PREISLER, J.; CVACKA, J.; KRASULOVÁ, J.; ROSIIN, Y. Explosive Backpacks in Old Termite Workers, Science, USA, v. 337, n. 6093 p. 436, 2012.

WALLER, D. A.; LAFAGE, J. P.; Nutritional ecology of termites, In Slansky Rodriquez, E.J.G., Nutritional Ecology of Insects, Mites, and Spiders, John Wiley \& Sons. 1987.

WILSON E, O.; HOLLDOBLER, B. Eusociality: origin and consequences, National Academy of Sciences, Cambridge ,v. 102, n. 38, p. 13367-13371, 2005.

YOUNG, R. J.; COELHO, C. M.; WIELOCH, D. R. A note on the climbing abilities of giant anteaters, Myrmecophaga tridactyla (Xenarthra, Myrmecophagidae), Bol. Mus. Biol. Melo Leitão, v. 15, Santa TeresaES, p. 41-46, Jul, 2003. 